\title{
Impact of Ownership Structure and Corporate Governance on Capital Structure of Pakistani Listed Companies
}

\author{
Arshad Hasan (Corresponding author) \\ ACMA, APA, MSc (Mathematics), MBA (IT), MS (Finance) \\ Muhammad Ali Jinnah University \\ Blue Area Islamabad, Pakistan \\ Tel: 92- 051-111-87-87 E-mail: aarshad.hasan@gmail.com
}

\author{
Safdar Ali Butt \\ Muhammad Ali Jinnah University Islamabad \\ Dean Faculty of Management and Social Sciences \\ Muhammad Ali Jinnah University \\ Blue Area Islamabad, Pakistan
}

Tel: 92 -051 -111-87-87

\begin{abstract}
This paper explores the relationship between corporate governance and capital structure of listed companies in an emerging equity market, Pakistan. The study covers the period 2002 to 2005 for which firm level data for 58 randomly selected non-financial listed companies from Karachi Stock Exchange has been examined by using multivariate regression analysis under fixed effect model approach. Measures of corporate governance employed are board size, board composition, and CEO/Chair duality. Impact of shareholding on financing decisions has also been examined by using managerial shareholding and institutional shareholding. Similarly influence of controlled variables like firm size and profitability on firms' financing mechanism is also investigated. Results reveal that board size and managerial shareholding is significantly negatively correlated with debt to equity ratio. However corporate's financing behavior is not found significantly influenced by $\mathrm{CEO} /$ Chair duality and the presence of non-executive directors on the board. However, control variables firm size and return on assets are found to have a significant effect on capital structure. No temporal effects are observed. Therefore results suggest that corporate governance variables like size and ownership structure and managerial shareholding play important role in determination of financial mix of the firms.
\end{abstract}

Keywords: Corporate governance, Ownership structure, Capital structure

1. Introduction

Corporate governance is a philosophy and mechanism that entails processes and structure which facilitate the creation of shareholder value through management of the corporate affairs in such a way that ensures the protection of the individual and collective interest of all the stakeholders. Sound corporate governance principles are the foundation upon which the trust of investors and lenders is built. Good corporate governance practices may have significant influence on the strategic decisions of a company, e.g. external financing, that are taken at board level. Therefore corporate governance variables like size of board, composition of board, skill set at board and $\mathrm{CEO} /$ Chair duality may have direct impact on capital structure decisions.

Corporate governance is generally associated with the existence of agency problem and its roots can be traced back to separation of ownership and control of the firm. Agency problems arise as a result of the relationships between shareholders and managers and are based on conflicts of interest within the firm. Similarly conflict of interests between controlling shareholders and minority shareholders is also at the heart of the corporate governance literature. According to modern corporate finance theories, agency cost is one of the determinants of capital structure. However empirical 
literature on corporate governance does not provide any conclusive evidence on the existence of relationship between corporate governance, ownership structure and capital structure of firm.

The corporate governance has been a growing area of management research. A comprehensive review of literature reveals that empirical work is mostly focused on the impact of corporate governance on firm's performance or examines the influence of ownership structure on firm value (Claessens, 2002). However relationship between corporate governance and capital structure has not been fully explored. Only few studies discuss the said relationship. Berger (1997), Friend and Lang (1988), Wen (2002) and Abor (2007) discuss the influence of corporate governance on the capital structure decisions of firms for developed and emerging markets. But no such study has been conducted to investigate the relationship between corporate governance and capital structure for Pakistani listed companies. Pakistan is an emerging market of South Asia and in recent past has shown remarkable performance, attracting considerable direct foreign investment. We believe, it is about time to explore the impact of corporate governance and ownership structure on firms' capital structure decisions.

According to modern corporate finance theories, agency cost is one of the determinants of capital structure whereas corporate governance is structured to alleviate agency issues; hence corporate governance and capital structure are linked through their association with agency costs. This paper integrates various strands of the literature and examines the effects of corporate governance and ownership structure on capital structure decisions of Pakistani listed companies since the promulgation of Code of Corporate Governance by Securities Exchange Commission of Pakistan in 2002. Study examines the impact of three sets of variables on capital structure. The first set includes corporate governance variables represented by Board Size, Composition of Board and CEO/Chair Duality. The second set comprises ownership variables which include Managerial Shareholding and Institutional Shareholding. The third set consists of control variables which include Size of Firm and Profitability. The capital structure is represented by debt to equity ratio.

This paper has been structured as follows:

- Section I is introduction.

- Section II provides an overview of existing literature on the subject.

- Section III explains the data, variables and methodology employed during empirical work.

- Section IV presents and discusses the findings of the study.

- Finally, Section V briefly concludes the whole discussion.

\section{Literature review}

\subsection{Ownership structure and capital structure}

Jensen and Meckling (1976) argue that managerial shareholding reduces managerial incentives to consume perquisites and expropriate shareholders' wealth and results in alignment of the interests of management and shareholders. It also reduces the propensity to involve in non maximizing behavior. Fama and Jensen (1983) and Demsetz (1983) argue that managerial shareholding may still have adverse effects on agency conflicts and it may entrench the present management leading to an increase in managerial opportunism. Jensen (1986) a gain addresses the issue of agency theory and finds that managers of a firm may make efforts to expand the firm beyond its optimal size for their personal gains and this may result in increase in gearing levels. These efforts may lead to greater power and status for managers but it will have a negative impact on firm efficiency.

Friend, Irwin and Lang (1988) discuss role of managerial self-interest in making capital structure decisions. They find that there exist negative relationship between leverage ratio and management's shareholding. This indicates that in the absence of any outsider principal stockholder the tendency of low debt to equity ratio will continue which will lead to higher non diversifiable risk of debt to management

Berger, Philip, Eli and Yermack (1997) investigate the relationship between managerial entrenchment and firms' capital structures. Results indicate that entrenched CEOs make efforts to remain away from debt and gearing ratios remain lower in the absence of demand from owners. A critical examination of changes in leverage levels reveals that gearing levels moves upward when steps to reduce entrenchment are taken. These steps may include threats to managerial security through involuntary CEO replacements and the replacement in the board of directors.

Short, Keasey and Duxbury (2002) examine the influence of ownership structure on the financial structure of UK firms. Results reveal that there exist positive relationship between management ownership and leverage ratio whereas negative relationship is observed between large external equity holder's ownership and financial leverage. However, relationship between management ownership and leverage ratio is not significant in the presence of a large outside equity holders. These findings suggest that outside equity holders affects the agency costs of equity financing and debt financing. 
Brailsford (2002) finds that the managerial ownership and leverage may be related in nonlinear fashion. He provides evidence about the presence of negative relationship among managerial equity holding and gearing levels. He discovers that low level ownership by managers leads to low level of agency conflicts and results in higher level of debt. On the other hand higher levels managerial ownership results in managerial opportunism and ultimately leads to lower debt levels.

\subsection{Board size and capital structure}

The board of directors is highest body of a company that is responsible for managing the firm and its operation. It plays vital role in strategic decisions regarding financial mix. Pfeffer and Salancick (1978) find a significant relationship between capital structure and board size. The evidence regarding direction of relationship between board size and capital structure is mixed.

Berger (1997) finds that firms with larger board of directors generally have low gearing levels. He argues that larger boards exert pressure on managers to follow lower gearing levels and enhance firm performance. Abor and Biekpe (2007) examine the relationship between corporate governance and capital structure decisions of Ghanaian Small and Medium Enterprises by using multivariate regression analysis. The results provide evidence about negative relationship between board size and leverage ratios and SMEs with larger boards generally have low level of gearing.

On the other hand, Wen (2002) finds positive relationship between board size and capital structure. He argues that large boards follow a policy of higher levels of gearing to enhance firm value especially when these are entrenched due to greater monitoring by regulatory authorities. It is also argued that larger board may find difficulty in arriving at a consensus in decision which can ultimately affect the quality of corporate governance and will translate into higher financial leverage levels. Jensen (1986) states that companies with high gearing level rather have larger boards. Anderson (2004) finds that the cost of debt is generally lower for larger boards because lenders think that these companies are being monitored more effectively by a diversified portfolio of experts. So debt financing becomes a cost effective choice.

\subsection{Non executive directors and capital structure}

Non executive directors are cornerstone of modern corporate governance. The relationship between presence of non executive directors and capital structure has been explored by few researchers but evidence in this regard is mixed. Some representative work is reviewed below.

Pfeffer and Salancick (1978) accentuate that non executive directors plays a pivotal role in enhancing the capability of a company to get recognition from external stake holders. Thus leads to reduction in uncertainty about company and enhance ability of the company to raise funds. They find that higher level of representation of non executive directors on board leads to higher gearing levels. Jensen (1986)and Berger (1997) find e that companies with higher gearing levels rather have relatively more non executive directors whereas companies with lower representation of non executive directors experience lower leverage. Abor and Biekpe (2007) provide evidence about the presence of positive relationship among gearing levels and CEO duality, board skills and board composition. Ghanaian SMEs that have more outside directors and a diversified set of skills at board generally have higher level of gearing.

On the other hand researchers like Wen (2002) provides evidence about the existence of significantly negative relationship between gearing level and representation of non executive directors on the board. The possible reason is that non executive directors monitor the managers more efficiently and effectively so managers are forced to seek lower gearing levels for achieving superior results. Similarly companies with higher representation of non executive directors are bound to follow low financial leverage with a high market value of equity.

\subsection{CEO/Chair duality and capital structure}

Another important feature of modern corporate governance is CEO/Chair duality. It indicates the corporate management where the CEO also serves as chairman of the board. This situation has direct impact on the financing decision of the company.

Fama and Jensen (1983) argue that in a firm decision management and decision control functions should be separate. Decision management function encompasses the right to initiate and execute new proposals for the disbursement of the firm's resources while decision control function comprises of the right to approve and monitor those proposals. This separation is ensured through a set of internal checks and internal controls. This system facilitates the judicious utilization of firm's resources. Therefore the same system should be implemented at the premier level. Therefore role of chief decision management authority (CEO) should also be separated from role of chief decision control authority (chairman). Board of directors is the seat of premier level of decision control mechanism in the corporate structure so it must not be controlled by $\mathrm{CEO}$. Presence of $\mathrm{CEO} / \mathrm{Chair}$ duality signals the absence of separation of decision management and decision control and it ultimately leads to agency problems. 
Fosberg (2004) finds that firms with separate chairman and CEO employ the optimal amount of debt in their capital structures. He discovers that firms with separate CEO and chairman generally have higher financial leverage. However it is worth mentioning that this relationship is statistically insignificant. Abor and Biekpe (2007) also provide evidence about the presence of positive relationship between gearing levels and CEO duality.

\section{Control Variables and Capital Structure}

\subsection{Firm size and capital structure}

Relationship between size and leverage of a firm is discussed in two different contexts. One point of view supports positive relationship between firm size and leverage. Titman and Wessels(1988) state that large firms do not consider the bankruptcy costs in deciding the level of leverage as these are just a small percentage of the total value of the firm. Therefore large firms may prefer to use higher level of gearing. Friend and Lang (1988) and Marsh (1982) also support the positive relationship between size of firm and leverage levels.

Another group of researchers provides evidence about the existence of negative relationship between size of firm and leverage. Rajan and Zingales (1995) find that as large firms are generally well-established and have good performance track record, enabling them to issue equity at fair prices. In turn, this reduces their reliance on debt and therefore there exists negative relationship between size and leverage of the firm.

\subsection{Profitability and capital structure}

Myers and Majluf (1984) find that profitable firms generally have low gearing levels because these firms prefer internally generated funds over external financing. These results are in line with pecking order hypothesis.

\section{Data description and methodology}

This study analyses relationship between capital structure and corporate governance for 59 non-financial companies listed at Karachi Stock Exchange. The sample period is 7/2002 to 6/2005 which starts just after the promulgation of Code of Corporate Governance in Pakistan. Total data consists of 177 observations for 59 companies. Board Size, Board Composition, Proportion of Non-Executive Directors, CEO/Chair Duality, Institutional Shareholding and Shareholding of Board Members are used as measures of Corporate Governance. Similarly, impact of control variables like Return on Assets and Firm Size on capital structure has also been studied. Variables included in study have been measured as follows

\subsection{Dependent variable: capital structure - leverage}

Capital Structure is the dependent variable and it is quantified by using debt to equity ratio. Debt to equity ratio can be calculated either by using market value or by using book value. The use of book value measure of leverage has been preferred in this study. The reason is that optimal level of leverage is determined by the trade-off between the benefits and costs of debt financing. It is an established fact that prime benefit of leverage is debt-tax shield and it is available on book value of the debt. Secondly, leverage can be calculated either by using total debt or by using long term debt as a percentage of total equity. Long term debt is better option but in this study total debt to equity ratio has been used because in Pakistan a tendency to use short-term financing even for longer term funding needs is fairly prevalent. There are number of companies that do not have long term debt. There are a number of causes for this state of affair. The first is unwillingness of commercial banks to extend longer term facilities. The second is relative absence of financial institutions specializing in long term financing. The third reason is the nascent state of capital market for long term debt in the country. Currently, less than two dozen term finance certificates are being traded at Karachi Stock Exchange while the number of listed companies is well over 600. Most companies find it quite difficult to access the capital market for debt financing. Under these circumstances, we considered it wise to take the total debt figure for measuring the companies' gearing level.

\subsection{Independent variables}

\subsubsection{Board size}

The board of directors is apex body in the corporate set up, playing central role in a firm's strategic decisions like financial mix. It is therefore considered an important variable to study the impact of corporate governance on capital structure. The variable Board size is measured as logarithm of number of board members. It is hypothesized that larger boards have negative relationship with leverage.

\subsubsection{Board composition}

Presence of non-executive directors on a company's board gives signal to the market that company is being monitored efficiently so lenders consider company more credit worthy. In turn, this makes it easier for the company to raise long term funds through debt financing. It is hypothesized that higher representation of non-executive directors on board leads to higher gearing levels. Variable Board composition represents the proportion of non-executive directors on board and is calculated as the number of non-executive directors divided by total number of directors. 


\subsubsection{CEO/Chair Duality}

If a person holds both slots of chief executive officer and chairman than it may create agency problems. Higher level of control by CEO may lead to managerial opportunistic behavior and can lead to lower gearing levels under entrenchment hypothesis. It is hypothesized that $\mathrm{CEO} / \mathrm{Chair}$ duality is negatively related to leverage levels. The variable $\mathrm{CEO} / \mathrm{Chair}$ duality is included as a dummy variable. It is taken as 1 if CEO is chairman; otherwise it is taken as 0.

\subsubsection{Institutional Share Holding}

Presence of institutional shareholding in a company helps it to raise long term finance at an advantageous cost. In the first place, these institutional investors themselves act as a source of long term debt as they are willing to provide debt to a company over whose board they enjoy an influence. Secondly, these institutional investors serve as an effective monitoring device over the company's strategic decisions. They bring down the company's agency costs and also reduce managerial opportunism. This gives confidence to general public and other lenders - resulting in favorable terms of borrowing by the company. It is therefore hypothesized that firms with higher Institutional Shareholding are likely to have a higher debt to equity ratio. Institutional Shareholding is measured as percentage of shares held by institutions as disclosed in annual financial reports.

\subsubsection{Managerial Shareholding}

Large debt increases the threat of bankruptcy so higher managerial self interests in long term sustainability of the company may induce managers to reduce gearing levels. Therefore it is hypothesized that relationship between managerial equity holding and gearing levels is negative. Managerial shareholding is measured as percentage of shares held by members of board disclosed in annual financial reports.

\subsubsection{Size of firm}

Large firms generally have close links with their lenders and find it easy to arrange debt on favorable terms. So it is hypothesized that there exists a positive relationship between the Size of Firm and leverage level of the firm. The variable Size of Firm is measured as logarithm of total assets.

\subsubsection{Profitability- Return on Assets}

Pecking Order Theory of capital structure states that companies use internally generated funds as first priority to finance project. Then as second priority debt is used and finally option of equity is exercised to finance company projects. Therefore it is hypothesized that profitability of firms has negative relationship with leverage levels. In this study Return on Assets (ROA) is used as measure of profitability and it is calculated by dividing a company's net earnings by its total assets

\subsection{Specifications of the Econometric Model}

This study employs multivariate regression analysis in a panel data framework to measure the dependence of capital structure on corporate governance variables. The panel data analysis helps to explore cross-sectional and time series data simultaneously. Pooled regression has been used with assumption of constant coefficients. Constant coefficient model assumes intercept and slope terms are constant.

The general form of model is

$$
\begin{aligned}
& \text { LEV }_{\text {it }}=\beta_{0}+\beta_{1}(\log \text { BZ }) \\
& \beta_{7}(\text { it } \\
& \text { DUALITY })_{\text {it }}+\varepsilon_{\mathrm{t}}
\end{aligned}
$$

$$
\begin{aligned}
& \text { Where } \quad \text { LEV = Leverage } \\
& \text { BZ = Board size } \\
& \text { NED = Non Executive Directors } \\
& \text { INSTSH = Institutional Shareholding } \\
& \text { MANGSH = Managerial Shareholding } \\
& \text { ROA = Return on Assets } \\
& \text { SZ } \quad=\text { Size of Firm } \\
& \text { DUALITY= CEO/Chair Duality } \\
& \begin{array}{l}
\varepsilon \quad=\text { Error Term } \\
\beta_{0} \quad=\text { Intercept of the equation } \\
\beta_{\mathrm{i}} \quad=\text { marginal effect of variable on debt to equity ratio }
\end{array}
\end{aligned}
$$




\section{Empirical results}

Table 1 exhibits the descriptive statistics. Results reveal that average size of board in Pakistani listed companies is 8.5 with largest board of 19 members and minimum board of size 7 (which is the statutory lower limit for a public company). Non-executive directors (NEDs) constitute $48 \%$ of boards which is a fairly good representation. However, it cannot be said with any certainty that these NEDs are also independents (INEDs) Managerial ownership is approximately $21 \%$ which is significantly high in textile and sugar sector and significantly low in oil and gas sector. Institutional shareholding is $15 \%$ which is reasonable, however it is not as well spread out across companies as it should be. Average rate of return on assets is $8 \%$. Average (total) debt to equity ratio is 1.48 representing a fairly reasonable overall capital mix.

Table 2 shows the results of correlation analysis.

- Profitability is negatively correlated with debt to equity ratio which is consistent with pecking order theory that firms use internally generated funds as first option to finance projects before resorting to debt.

- There is a positive relationship between leverage and the size of firm. This appears rational as larger firms have more assets for collateral and it is easier for them to negotiate better terms with lenders. It may also be pointed out here that in Pakistan, most commercial banks are very conservative in their lending policies. Prudential Regulations prescribed by State Bank of Pakistan make it extremely difficult for commercial banks to be adventurous in their lending policies. Hence, presence of a large assets base is necessary for any borrowing, long or short term.

- Correlation analysis indicates that managerial holding is negatively correlated with debt to equity ratio. This is quite consistent with other studies which argue that as managers' shareholding in a company increases, they tend to bring down the size of firm's debt to reduce the risk and costs of bankruptcy. In Pakistani context, management controlled companies are generally those whose majority equity is held by families. Families are always averse to the thoughts of bankruptcy and refrain from incurring higher debts.

- Institutional share holding is positively correlated with capital structure. This positive relationship is result of efficient monitoring and reduction of the agency cost and managerial opportunism. Temporal effect has also been tested but result is found insignificant for time dummies

- The size of board is found negatively correlated with debt to equity ratio indicating larger boards may exert pressure on managers to follow lower gearing levels and enhance firm performance. An aspect of this observation is that larger companies have larger boards - and larger companies with larger assets base are more inclined to incur debt at favorable terms.

- Relationship between NEDs and shareholding is negative which shows that concentration of ownership leads to reduce the presence of NEDs on boards. This results in establishment of stronger control on firms. This phenomenon is common in family owned businesses and it can be said that Pakistani equity market is dominated by family owned companies. Domination of a board by a close family and absence of a reasonable number of INEDs are the practices that are generally deemed against the spirit of good corporate governance. These practices adversely affect the performance of company as shown by the relationship between Return on Assets and managerial shareholding.

Table 3 presents results of multivariate regression analysis

$\mathrm{LEV}_{\text {it }}=2.44-1.85(\log \mathrm{BZ})_{\text {it }}+0.17(\% \mathrm{NED})_{\mathrm{it}}+0.75(\% \mathrm{INSTSH})_{\text {it }}-0.90(\mathrm{MANGSH})_{\mathrm{it}}-4.95(\mathrm{ROA})_{\mathrm{it}}+0.35(\mathrm{SZ})_{\mathrm{it}}$ $-0.11\left(\right.$ DUALITY) ${ }_{\text {it }}+\varepsilon_{\mathrm{t}}$

Results reveal that:

- Multivariate regression analysis provides that an increase of $1 \%$ in Profitability leads to $4.95 \%$ decrease in leverage and this relationship is significant at $\alpha=0.05$. Results have economic relationship and are in inline with pecking order theory which assumes that profitable firms use internally generated fund for financing as first choice.

- Debt to equity ratio is significantly affected by Size of the firm and an increase in size increase the tendency of the firm to exercise the mode of debt financing. Correlation analysis indicates the presence of insignificant relationship whereas regression analysis provides evidence about existence of significant relationship at $\alpha=0.05$. It may be due to the fact that large firms have established their reputation as successful organization and have tangible assets on balance sheet that can serve as collateral so it is relatively easier for large firms to secure debt financing on favorable terms.

- Regression analysis also provides evidence about the existence of significant negative relationship between size of board and debt to equity ratio. This relationship is consistent with results of correlation analysis and is also in line with Berger (1997) and Abor (2007) which argue that larger boards prefer low debt levels. Larger boards may emphasize owner-manager to employ more equity capital in order to improve firm performance.

- Presence of NED on the board has no significant impact on leverage. It may be due to fact that in family owned business NEDs are generally representatives of financial institutions, or hand picked nominees of the controlling 
shareholders. For NEDs to make a difference in company's strategic decision making process, it is important that they should be independent non-executive directors (INEDs). A mere NED is in fact quite ineffective, particularly in Pakistani context. Again, the distinction between INEDs and NEDs is also quite blurred in the Pakistani scenario as no statistics are available about this very important aspect of corporate governance. The Code of Corporate Governance has not made it mandatory to have independent directors on the highest forum of corporate decision making. Hence, we believe this finding needs greater attention than was possible to give in the present study. Similarly, institutional shareholding and $\mathrm{CEO} /$ Chair duality has insignificant impact on debt to equity ratio which also substantiates the above justification.

- Managerial ownership is significantly affects capital structure represented by debt to equity ratio. An increase in managerial share holding by $1 \%$ leads to reduction in leverage by $0.9 \%$. It may be argued that higher levels of debt increase the probability of default and managerial interests in long term viability persuade them to exercise the option of lower leverage levels. These results are in line with Friend, Irwin and Lang (1988) who argue that in the absence of any external significant shareholding the propensity to have lower debt to equity ratio will persist and will result in higher non-diversifiable risk of debt to management.

\section{Conclusion}

This paper empirically examines the relationship between corporate governance, ownership structure and capital structure for Pakistani non-financial listed companies for the period 2002-2005 by using multivariate regression analysis. Results reveal that board size is significantly related to capital structure. However representation of NEDs on board and CEO/Chair Duality has no significant relationship with capital structure. One possible explanation for this situation may be that in Pakistan NEDs are not independent in true sense. However correlation analysis suggests that $\mathrm{CEO} /$ Chair Duality and manager ownership are negatively correlated with profitability.

On the other hand managerial ownership has negative relationship with debt to equity ratio indicating that concentration of ownership induces the managers to lower the gearing levels. Institutional ownership has positive relationship with capital structure which is consistent with corporate governance philosophy but this relation is statistically insignificant. This may be due to the fact that corporate governance practices are still in an infancy phase in Pakistan. In family-owned and close-held companies it takes considerable time to accept any change that runs counter to the momentum set by history.

Traditional determinants of capital structure like size and profitability have significantly effect on corporate financing decisions. Profitability is negatively related with debt to equity ratio and it is consistent with pecking order hypothesis. Similarly, size has positive relationship which shows that large firms can arrange debt financing due to long term relationship and better collateral offering. Therefore we can conclude that corporate governance and ownership structure has important implications on the financing decisions.

\section{References}

Abor, J. (2007). Corporate Governance and Financing Decisions of Ghanaian Listed Firms, Corporate Governance: International Journal of Business in Society, 7.

Anderson R., Mansi, S. and Reeb, D. (2004). Board Characteristics, Accounting Report Integrity and the Cost of Debt, Journal of Accounting and Economics, 37, 315-342.

Berger, P. G., Ofek, E. and Yermack, D. L. (1997). Managerial Entrenchment and Capital Structure Decisions, Journal of Finance, 52(4), 1411-1438.

Fama, E., and Jensen, M. (1983). Separation of Ownership and Control, Journal of Law and Economics, 26(2), 301-325.

Friend, I. and Lang, L.H.P. (1988). An Empirical Test of the Impact of Managerial Self- interest on Corporate Capital Structure. Journal of Finance, 47, 271-281.

Helen Short, Kevin Keasey and Darren Duxbury. (2002). Capital Structure, Management Ownership and Large External Shareholders: A UK Analysis. International Journal of the Economics of Business, Vol. 9(3), pp. 375-399.

Harris, M. and Raviv, A. (1988). Corporate Control Contests and Capital Structure. Journal of Financial Economics, 20, 55-86.

Jensen, M. C. (1986). Agency Costs of Free Cash Flow, Corporate Finance and Takeovers. American Economic Review, 76, 323-329.

Jensen, M.C. and Meckling, W.H. (1976). Theory of the Firm: Managerial Behaviour, Agency Costs and Capital Structures. Journal of Financial Economics, 3, 305-360.

Mayer, C. (1988). New Issues in Corporate Finance. European Economic Review, Vol. 32, pp. 1167- 1189. 
Myers, S., and N. Majluf. (1984). Corporate Financing and Investment Decisions When Firms Have Information Investors Do Not Have. Journal of Financial Economics, 13, 187-222.

Modigliani, F. and Miller, M.H. (1958). The Cost of Capital, Corporation Finance the Theory of Investment. American Economic Review, 48, pp. 261- 97.

Pfeffer, J. (1973). Size, Composition and Function of Corporate Boards of Directors: the Organisation-environment linkage. Administrative Science Quarterly, 18, pp. 349-364.

Pfeffer, J. and Salancick, G.R. (1978). The External Control of Organisations: a Resource-dependence Perspective. Harper \& Row, New York.

Stephen A. Ross. (1977). The Determination of Financial Structure: the Incentive-Signalling Approach. Bell Journal of Economics, Vol. 8(1), pp. 23-40.

Stultz, R. (1990). Managerial Discretion and Optimal Financing Policies. Journal of Financial Economics, Vol. 26, pp. $3-27$.

Wen, Y., Rwegasira, K. and Bilderbeek, J. (2002). Corporate Governance and Capital Structure Decisions of Chinese Listed Firms. Corporate Governance: An International Review, 10, 2, pp. 75-83.

Table 1. Descriptive Statistics

\begin{tabular}{|c|c|c|c|c|c|c|c|}
\hline & Leverage & $\begin{array}{c}\text { Board } \\
\text { Size }\end{array}$ & \% NED & Inst. Hold & $\begin{array}{c}\text { Managerial } \\
\text { holding }\end{array}$ & $\begin{array}{c}\text { Log } \\
\text { ROA }\end{array}$ & \begin{tabular}{c} 
(Total Asset) \\
\hline Mean
\end{tabular} \\
\hline Median & 1.48 & 8.46 & 0.48 & 0.15 & 0.21 & 0.08 & 3.35 \\
\hline Std Dev & 1.14 & 8.00 & 0.57 & 0.12 & 0.09 & 0.06 & 3.47 \\
\hline Kurtosis & 3.88 & 6.12 & 0.27 & 0.12 & 0.24 & 0.07 & 0.64 \\
\hline Skewness & 1.80 & 2.36 & -0.35 & 0.72 & -0.24 & 0.97 & -0.79 \\
\hline Minimum & 0.05 & 7.00 & 0.00 & 0.00 & 0.00 & -0.16 & 1.96 \\
\hline Maximum & 6.52 & 19.00 & 1.00 & 0.56 & 0.86 & 0.30 & 4.80 \\
\hline
\end{tabular}

Table 2. Correlation Matrix

\begin{tabular}{|c|c|c|c|c|c|c|c|c|}
\hline & Leverage & $\begin{array}{c}\text { log } \\
\text { Board } \\
\text { Size }\end{array}$ & $\begin{array}{c}\% \\
N E D\end{array}$ & $\begin{array}{l}\text { Inst. } \\
\text { Hold }\end{array}$ & $\begin{array}{c}\text { Managerial } \\
\text { holding }\end{array}$ & $\boldsymbol{R O A}$ & $\begin{array}{c}\text { Log(Total } \\
\text { Asset })\end{array}$ & Duality \\
\hline Leverage & 1.00 & & & & & & & \\
\hline log Board Size & -0.07 & 1.00 & & & & & & \\
\hline$\%$ NED & 0.04 & 0.10 & 1.00 & & & & & \\
\hline Inst. Hold & 0.15 & 0.09 & -0.28 & 1.00 & & & & \\
\hline Insider holding & -0.19 & -0.34 & -0.25 & -0.24 & 1.00 & & & \\
\hline ROA & -0.25 & 0.24 & 0.00 & -0.05 & -0.23 & 1.00 & & \\
\hline $\log (T$ Asset) & 0.14 & 0.40 & 0.02 & 0.13 & -0.46 & 0.34 & 1.00 & \\
\hline Duality & -0.07 & 0.10 & 0.18 & -0.10 & 0.03 & -0.03 & -0.09 & 1.00 \\
\hline
\end{tabular}

Table 3. Results Multivariate Regression Analysis

\begin{tabular}{|c|c|c|c|}
\hline & Coefficients & t Statistics & P-value \\
\hline Intercept & 2.44 & 2.52 & 0.01 \\
\hline $\log$ Board Size & -1.85 & -1.98 & 0.05 \\
\hline \% NED & 0.17 & 0.50 & 0.31 \\
\hline Inst. Hold & 0.75 & 1.03 & 0.04 \\
\hline Managerial Holding & -0.90 & -2.12 & 0.00 \\
\hline ROA & -4.95 & -4.14 & 0.02 \\
\hline
\end{tabular}

